\title{
Synthesis of the Maduropeptin Chromophore Aglycon
}

\section{Key words}

macrocyclization

Sonogashira coupling

reductive elimination

enediynes<smiles>C#CC(=O)C1[C@@H](OCCO)CC[C@H]1O</smiles><smiles>COc1ccc(C(O)CCO)c(Cl)c1O</smiles>

\section{$\underset{74 \%}{\mathrm{CsF}, \mathrm{DMF}, 80^{\circ} \mathrm{C}}$}

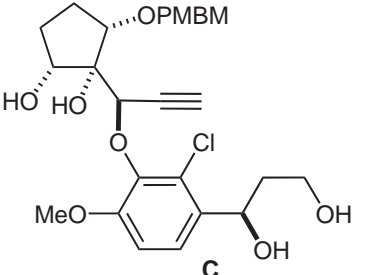

c

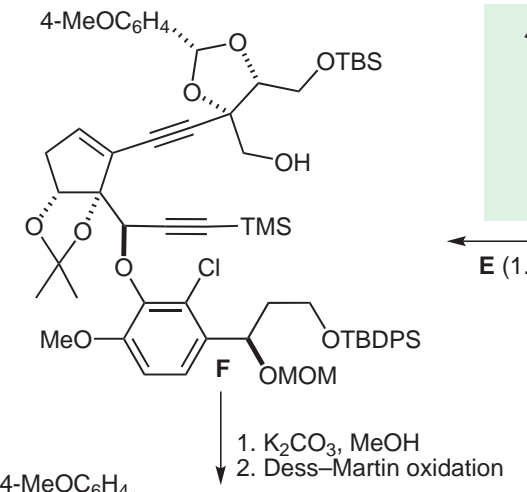

4- $\mathrm{MeOC}_{6} \mathrm{H}_{4}$

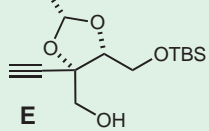

(1.0 equiv), $\mathrm{Pd}\left[\mathrm{PPh}_{3}\right)_{4}(5 \mathrm{~mol} \%)$ Cul, DIPEA, DMF $>83 \%$

Sonogashira coupling 2. Dess-Martin oxidation
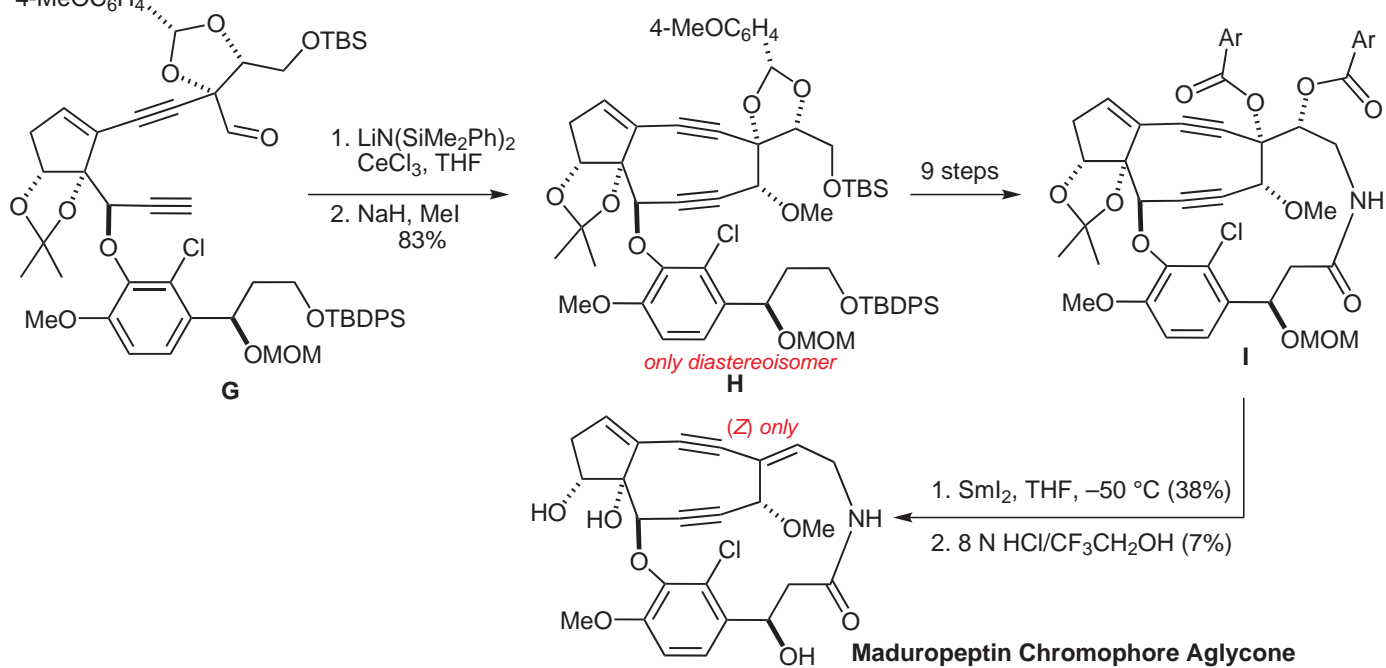

Significance: The target is an extremely labile precursor to an enediyne intermediate whose cycloaromatization to a $p$-benzyne biradical efficiently cleaves DNA by $\mathrm{H}$-abstraction. The target was constructed from three major fragments $\mathbf{A}, \mathbf{B}$, and $\mathbf{E}$.
Comment: The cyclization $\mathbf{G} \rightarrow \mathbf{H}$ and the penultimate $\mathrm{Sml}_{2}$-mediated reductive elimination were highly diastereoselective. The final deprotection step ( $7 \%$ yield) gave the target as a single atropisomer.

SYNFACTS Contributors: Philip Kocienski

Synfacts 2008, 4, 0329-0329 Published online: 19.03.2008

DOI: 10.1055/s-2008-1042884; Reg-No.: K02508SF 